\title{
ECONOMICS AND POLITICS
}

\author{
BY \\ MORITZ JULIUS BONN
}

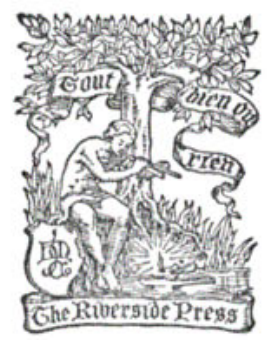

\section{BOSTON AND NEW YORK HOUGHTON MIFFLIN COMPANY Utye Ribersite press Cambrioge \\ I932}


COPYRIGHT, 1932, BY THE REGENTS OF THE UNIVERSITY OF CALIFORNIA

ALL RIGHTS RESERVED INCLUDING THE RIGHT TO REPRODUCE THIS BOOK OR PARTS THEREOF IN ANY FORM

The Ratbersibe Press

CAMBRIDGE - MASSACHUSETTS

PRINTED IN THE U.S.A. 


\section{BARBARA WEINSTOCK LECTURES ON THE MORALS OF TRADE}

This series will contain essays by representative scholars and men of affairs dealing with the various phases of the moral law in its bearing on business life under the new economic order, first delivered at the University of California on the Weinstock Foundation. 
